\title{
Smoothelin in vascular smooth muscle cells
}

Citation for published version (APA):

van Eys, G. J. J. M., Niessen, P. M. G., \& Rensen, S. S. M. (2007). Smoothelin in vascular smooth muscle cells. Trends in Cardiovascular Medicine, 17 (1), 26-30. https://doi.org/10.1016/j.tcm.2006.11.001

Document status and date:

Published: 01/01/2007

DOI:

10.1016/j.tcm.2006.11.001

Document Version:

Publisher's PDF, also known as Version of record

Document license:

Taverne

\section{Please check the document version of this publication:}

- A submitted manuscript is the version of the article upon submission and before peer-review. There can be important differences between the submitted version and the official published version of record.

People interested in the research are advised to contact the author for the final version of the publication, or visit the DOI to the publisher's website.

- The final author version and the galley proof are versions of the publication after peer review.

- The final published version features the final layout of the paper including the volume, issue and page numbers.

Link to publication

\footnotetext{
General rights rights.

- You may freely distribute the URL identifying the publication in the public portal. please follow below link for the End User Agreement:

www.umlib.nl/taverne-license

Take down policy

If you believe that this document breaches copyright please contact us at:

repository@maastrichtuniversity.nl

providing details and we will investigate your claim.
}

Copyright and moral rights for the publications made accessible in the public portal are retained by the authors and/or other copyright owners and it is a condition of accessing publications that users recognise and abide by the legal requirements associated with these

- Users may download and print one copy of any publication from the public portal for the purpose of private study or research.

- You may not further distribute the material or use it for any profit-making activity or commercial gain

If the publication is distributed under the terms of Article $25 \mathrm{fa}$ of the Dutch Copyright Act, indicated by the "Taverne" license above, 


\title{
Smoothelin in Vascular Smooth Muscle Cells
}

\author{
Guillaume J. van Eys*, Petra M. Niessen, and \\ Sander S. Rensen
}

\begin{abstract}
Smoothelin-A and -B have only been found in fully differentiated contractile smooth muscle cells. They are increasingly used to monitor the smooth muscle cell differentiation process to a contractile or synthetic phenotype. Vascular-specific smoothelin-B is the first smooth muscle cell marker that disappears when vascular tissues are compromised, for example, in atherosclerosis or restenosis. Recently obtained data show that smoothelin deficiency results in a considerable loss of contractile potential and hence in impaired smooth muscle function and suggest that smoothelins are part of the contractile apparatus. (Trends Cardiovasc Med 2007;17:26-30) (C) 2007, Elsevier Inc.
\end{abstract}

\section{- Introduction}

Associated with different functional qualities, smooth muscle cells (SMCs) come in a variety of phenotypes. Depending on the type, developmental stage, and condition of the tissue, SMC phenotypes can vary from contractile to synthetic/proliferative. Classically, SMC phenotypic diversity has been described in morphological terms (ChamleyCampbell et al. 1979). Characterization has been refined by the application of a number of phenotype-specific marker proteins. The phenotypic diversity observed in vitro has also been found in vivo, where SMCs display a large variation in phenotype among and even

Guillaume J. van Eys, Petra M. Niessen, and Sander S. Rensen are at the Department of Molecular Genetics, Cardiovascular Research Institute Maastricht, University of Maastricht, 6200 MD Maastricht, The Netherlands.

* Address correspondence to: Guillaume J. van Eys, Department of Molecular Genetics, University of Maastricht, PO Box 616, 6200 MD Maastricht, The Netherlands. Tel.: $(+31)$ 043-388-1355;

e-mail: g.vaneys@gen.unimaas.nl.

(c) 2007, Elsevier Inc. All rights reserved. 1050-1738/07/\$-see front matter within tissues. Phenotypic flexibility is necessary for SMCs to cope with varying conditions in hollow organs. Switches in gene expression that modulate the phenotype direct the adaptations of SMCs. More than 10 years ago, Gary Owens published a scheme positioning marker proteins along a differentiation axis, combining embryonic appearance with morphological characteristics (Owens 1995). Such a scheme supposes a direct relation between marker expression and SMC phenotype. Although this still is largely true, a more complex and detailed picture of SMC phenotypic modulation has become apparent and is in part the result of new markers that have become available (Owens et al. 2004). Smoothelins are recent additions to the set of SMC markers. This review summarizes their significance as phenotypic markers and their relevance for SMC function.

\section{- Discovery of Smoothelins}

Ten years ago, a monoclonal antibody (generated against chicken gizzard) was observed to react with a hitherto unknown component that was only found in smooth muscle tissue. Analysis of a panel of tissues showed that the antibody reacted with all smooth muscle tissues (visceral as well as vascular) of a large variety of vertebrates (human to fish). The antibody was used to select a cDNA from a human intestinal smooth muscle cDNA library. This cDNA coded for an unknown 59-kDa protein that was designated smoothelin. The gene was cloned, and it was shown that the last three exons of the gene shared homology with genes of members of the spectrin protein family, coding for a "calponinhomology domain' (Figure 1). For other structural proteins, it has been shown that this domain, in a tandem repeat, preferentially binds to actin (Korenbaum and Rivero 2002, Gimona et al. 2002). The colocalization of smooth muscle $\alpha$-actin (SM $\alpha$-actin) and smoothelin, as demonstrated in primary SMCs (van der Loop et al. 1996, Christen et al. 1999) (Figure 2), indicates that the domain is functional. In collaboration with the group of Giulio Gabbiani, we showed that the single calponin homology domain is sufficient to establish a bond between smoothelin and filamentous actin, although the presence of other, not yet defined, domains is apparently necessary to facilitate and/or strengthen the binding to actin (Niessen et al. 2004a). Based on sequence comparison, Quensel et al. (2002) claimed that smoothelin contains troponin-like elements, but no physical implication has been mentioned.

Meanwhile, it was found that vascular tissues contained a larger smoothelin isoform (approximately $110 \mathrm{kDa}$ ). The vascular smoothelin, designated smoothelin-B, includes the complete smoothelin found in the viscera, which was then redesignated smoothelin-A (Figure 1). Transcripts for both smoothelin-A and -B are generated from a single-copy gene on human chromosome 22. Smoothelin-B is encoded by 21 exons, whereas smoothelin-A transcription starts in the middle of exon 10. The two transcripts are generated from the gene by two physically separated promoters. Remarkably, expression of smoothelin-A is under control of an intragenic promoter consisting of several exons of smoothelin-B (Figure 1). The promoter of smoothelin- $\mathrm{B}$ is in a more conventional position directly upstream of the first exon (Rensen et al 2002). 


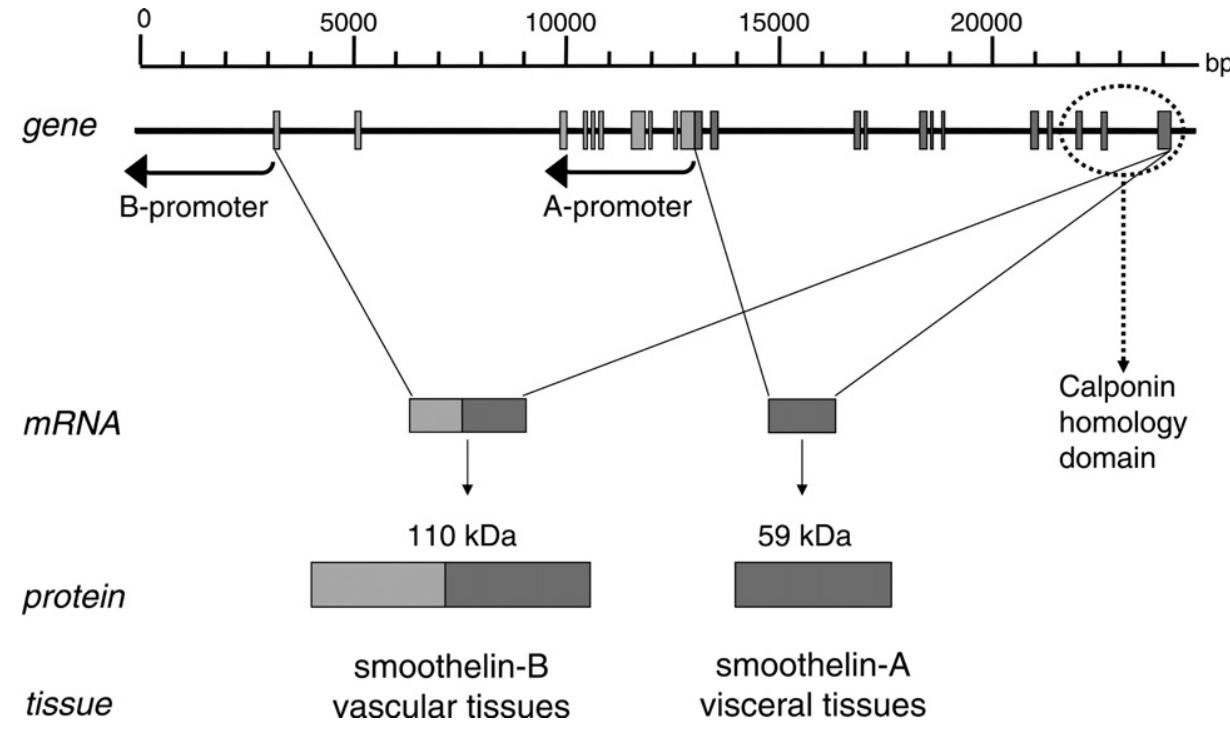

Figure 1. Gene structure and expression of smoothelins. Exon-intron organization of the human smoothelin gene is depicted. The dark gray boxes represent exons coding for smoothelinA as well as smoothelin-B, the light gray boxes are smoothelin-B-specific. The promoters of both transcripts are indicated by arrows, whereas the calponin homology domain is indicated by a dotted line. Furthermore, the gene transcripts and final protein products are shown.

\section{- Expression of Smoothelins In Vitro}

The contractile phenotype specificity of smoothelin expression became first apparent when SMCs were brought into culture. Smoothelin expression rapidly ceased, paralleling the shift toward a synthetic phenotype. The concentration of smoothelin mRNA of intestinal SMCs in culture fell within $12 \mathrm{~h}$ to hardly detectable levels, although smoothelin protein lingered for several days (van der Loop et al. 1996). Serum starvation or addition of compounds such as heparin resulted in the maintenance of detectable smoothelin levels for a prolonged period (Christen et al. 1999). So far, only few SMC systems have been described in which smoothelin synthesis could be induced (van der Veer et al. 2005, Rodriguez et al. 2006, Hao et al. 2002). However, in general, once smoothelin expression has ceased, it appears to be nearly impossible to reexpress smoothelin protein in vitro. Nevertheless, several groups have found smoothelin transcripts in cultured SMCs by reverse transcriptase-polymerase chain reaction (RT-PCR) (Niu et al. 2001, Morrow et al. 2005, Yoshida et al. 2004), which may be indicative of the epigenetic state of the gene in proliferating cells.

To be able to study smoothelin function, we performed transfections in SMC lines. Although the number of trans-
Analysis of the two smoothelin promoters showed that they both differ from most of the promoters of other genes that are specifically expressed in the smooth muscle. The extraordinary tissue-specific expression pattern of smoothelin-A and -B may in part be explained by the different structure of the promoters and their different mode of interaction with transcription factors. For instance, in collaboration with the group of Joe Miano, we showed that the smoothelin-B promoter lacks conserved CArG boxes, considered to be a key feature for muscle-specific expression (Miano 2003). On the other hand, the smoothelin-A promoter does contain conserved CArG boxes, but up-regulation of expression after interaction with myocardin is low compared with other smooth-muscle-specific genes (Rensen et al. 2006). These results should be interpreted with caution because cultured SMCs express little or no smoothelin, suggesting that factors necessary for its full expression are lacking or are inhibited in cultured cells. Nevertheless, in vivo, the two promoters direct variable levels of smoothelin expression in a smooth muscle phenotype- and tissuespecific manner.

\section{- Embryonic Expression of Smoothelins}

Smoothelin expression in embryos differs from the pattern observed in adults. Abundant smoothelin expression is first observed in the heart and the somites (De Ruiter et al. 2001). Smoothelin deficiency in knockout mice, however, does not interfere with embryonic develop-
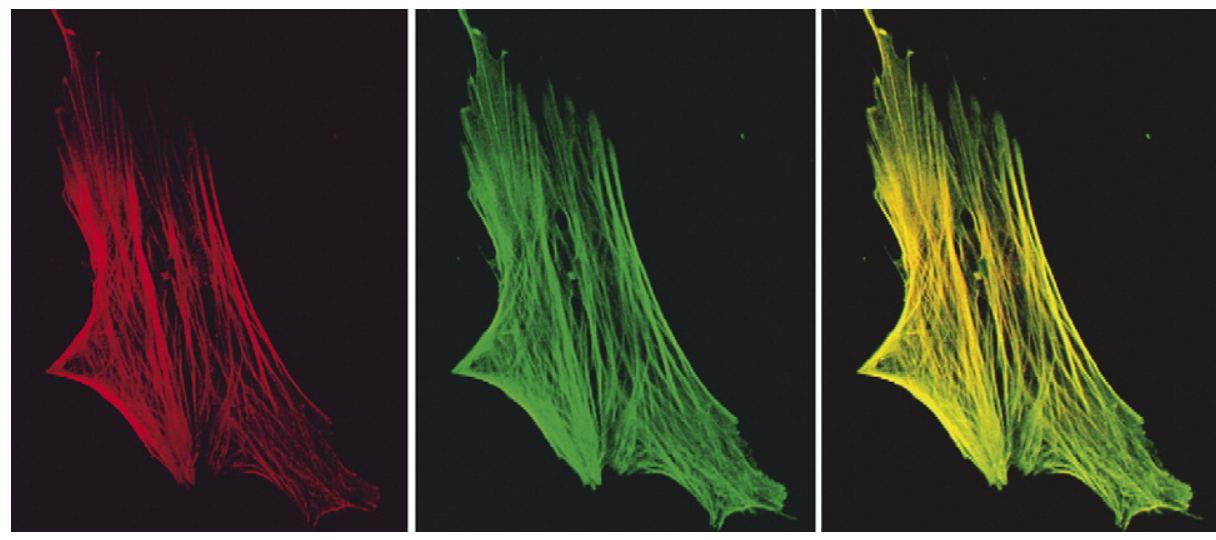

Figure 2. Colocalization of smoothelin and SM $\alpha$-actin in a porcine coronary artery SMC. Immunostaining with antibodies against smoothelin is shown in red and against SM $\alpha$-actin in green. In the right panel, the two stainings are merged, demonstrating that smoothelin and SM $\alpha$-actin colocalize (collaboration with Professor G. Gabbiani, Geneva). 


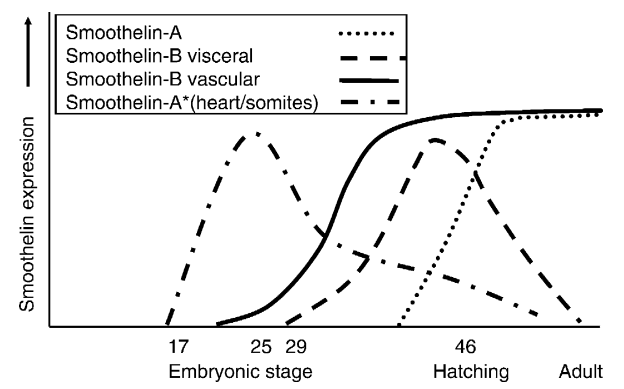

Figure 3. Schematic representation of the expression levels of the different smoothelin isoforms in various organs of the developing chicken embryo (based on De Ruiter et al. 2001). Although the physiological relevance of the isoform expression pattern is not clear, it may coincide with the type of contraction.

ment (Niessen et al. 2005). Smoothelin expression in the heart and somites is phased out in later stages of embryogenesis (Figure 3), although after-birth remnants of smoothelin expression have been observed in the heart, in particular in the trabeculae (De Ruiter et al. 2001, Johansson et al. 1999). The somewhat larger embryonic heart isoform has been shown to be a smoothelin-A variant that differs from the standard smoothelin-A by posttranslational modification (De Ruiter et al. 2001). In the second half of embryonic development, expression of smoothelins starts in the digestive tract and the vasculature. Surprisingly, it is the 'vascular' smoothelin-B that is found in the embryonic intestine. Around birth, the B-isoform is replaced by smoothelinA (De Ruiter et al. 2001) (Figure 3). The physiological meaning of this switch is not clear but may be related to the onset of peristalsis after birth. This is in line with smoothelin-A expression in the embryonic heart because the heart is also subject to phasic contractions. Smoothelin-B, on the other hand, may operate in more tonic contractions as performed by mature vascular smooth muscle. Such a differential expression has also been described for caldesmon (Guo and Wang 2005).

\section{- Smoothelin as a Marker of Contractile SMCs in Healthy and Diseased Tissue}

The phenotype specificity of smoothelins has been firmly established by different techniques (from immunohistochemistry to microarrays), and the use of smoothelin as a definitive marker of the SMC contractile phenotype, next to smooth muscle myosin heavy chain and SM22, is now widely accepted. In fact, smoothelin is the only marker that differentiates between SMCs and myofibroblasts (van der Loop et al. 1997, Maeng et al. 2003).

In vascular tissues, the level of expression of smoothelin-B is indicative of the type as well as the condition of the blood vessel. High levels are found in SMCs of arteries, and relatively low expression in SMCs of veins. Not all vascular SMCs in arterial media express smoothelin. In elastic arteries, such as the aorta, the percentage of smoothelinexpressing SMCs is lower than in muscular arteries, such as the femoral artery (van der Loop et al. 1997). In addition to these tissue-related differences, smoothelin concentration fluctuates with changing conditions. For example, van der Heijden et al. (2004), studying the uterine artery of mice during pregnancy, showed that fluctuations in the smoothelin content of the media coincide with the remodeling of this artery and are inversely correlated to the expression of Ki-67, a proliferation marker. During pregnancy, the murine uterine artery doubles in size to accommodate the increasing blood flow to the growing fetuses. The smoothelin concentration drops during the first half of pregnancy and starts to rise only after the vessel expansion starts to slow down. This and similar findings in other more pathology-related experimental setups (see below) indicate that smoothelin concentration has to decrease to facilitate the remodeling process. Thus, smoothelin appears to be a good marker to monitor SMC phenotypic shifts that occur during physiological vascular remodeling.

A number of vascular diseases are in part a process of pathological vascular remodeling, and in these cases, smoothelin is also increasingly used as a marker to evaluate the condition of the tissue. If the vessel wall is injured, it reacts by reinforcing the damaged area by proliferation and migration of SMCs into the intima, as seen in restenosis, or by formation of a fibrous cap, as seen in atherosclerosis. These processes are initiated by cytokines and growth factors that direct medial SMCs to proliferate. However, to start proliferation, the SMCs have to modulate toward a more synthetic phenotype, going through a series of events that include a shutdown of smoothelin expression. In restenosis, the smoothelin concentration in the SMCs of the affected area drops directly after angioplasty or stent placement (Christen et al. 2001, Bar et al. 2002, Maeng et al. 2003) (Figure 4). It stays
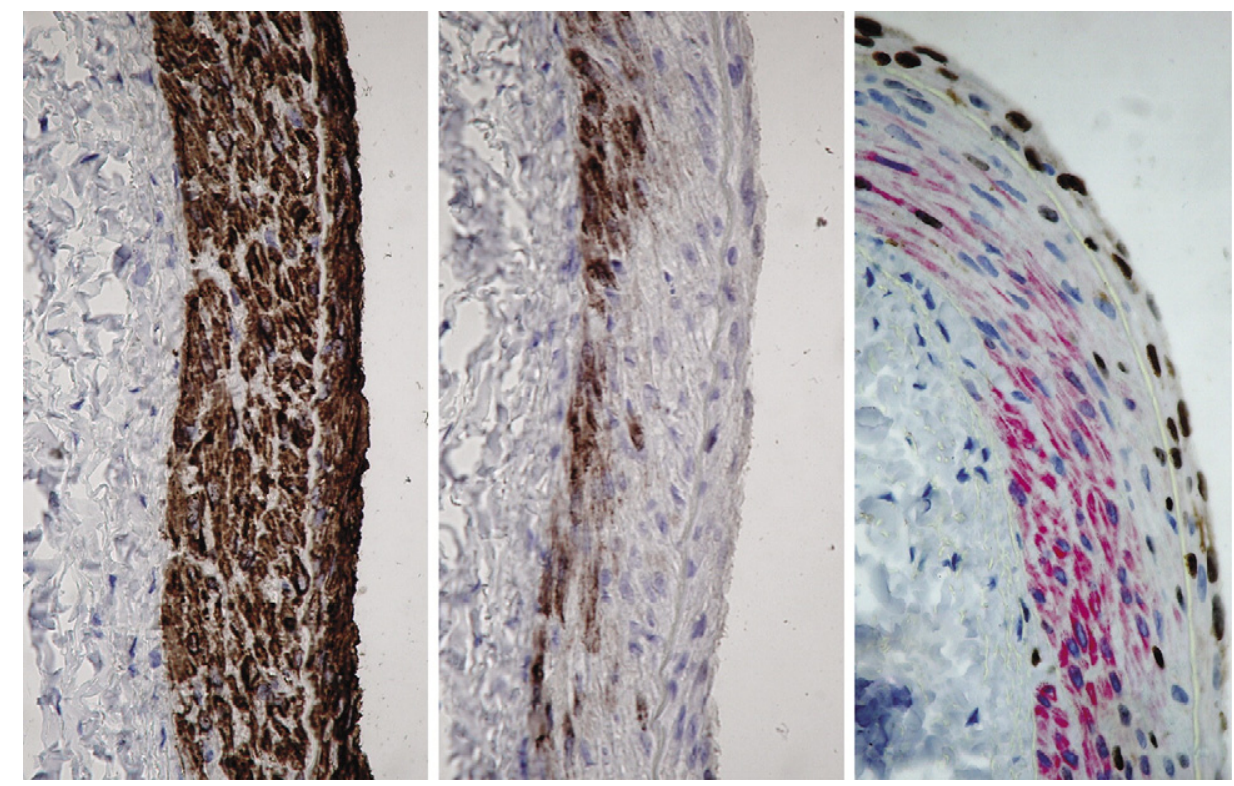

Figure 4. Smoothelin expression pattern in rabbit iliac arteries, 7 days after angioplasty (reprinted with permission from Maeng et al. 2003). Sections are stained for SM $\alpha$-actin (left panel), smoothelin (middle panel), and a double staining for smoothelin in red and Ki-67 in brown (right panel). Note that the smoothelin staining is restricted to the deeper layers of the media, whereas proliferation, as indicated by Ki-67, is found in the upper layers. 
low during migration and proliferation of the medial SMCs to the intima. When expansion of the SMCs ceases, they differentiate to a contractile phenotype, a process that is characterized by reexpression of smoothelin and smooth muscle myosin heavy chain. Work in pigs, rats, and rabbits has shown that in this sequence of events, smoothelin is the first marker to disappear after angioplasty and only returns after remodeling has been concluded (Christen et al. 2001, Bar et al. 2002, Maeng et al. 2003).

This is in line with findings in human saphenous veins prepared for bypass surgery. These veins are tested to confirm their capability to handle the pressure produced by the ejecting heart. During this process, smoothelin concentration drops by $60 \%$ (Johnson et al. 2001). This may be one of the factors that facilitate the intimal proliferation that eventually leads to graft failure.

Another disease in which the phenotype-specific expression of smoothelin becomes manifest is atherosclerosis. In atherosclerotic lesions, in humans or in animal models, smoothelin expression decreases in the media directly below the affected area (Verhamme et al. 2002, Tharp et al. 2006). Here, too, smoothelin staining is inversely correlated with Ki67 staining. During plaque formation, SMCs proliferate and migrate from the affected media into the lumen of the blood vessel to form a neointima that caps the necrotic core. The neointima contains little smoothelin, whereas SM $\alpha$-actin remains abundantly expressed (Hao et al. 2006, Tharp et al. 2006). However, in time, when the plaque becomes 'quiescent' and does no longer expand, smoothelin expression can be detected in SMCs of the cap (van der Loop et al. 1997). Both in restenosis and in atherosclerotic plaques, smoothelin expression is down-regulated in conjuncture with smooth muscle-myosin heavy chain and partly SM $\alpha$-actin, stressing its direct relation with contractility and, more precisely, the contractile apparatus. However, down-regulation of smoothelin expression is usually more rapid and more uniform as compared to these other SMC contractile proteins.

\section{- Putative Function of Smoothelin}

Although smoothelin is currently often used as a marker for contractile SMCs, knowledge about its function remains incomplete. Its suggested position in the contractile apparatus needs in vivo confirmation. Interruption of the smoothelin gene in mice, by removal of the calponin-homology domain, is lethal at young age and is dominated by effects on the intestinal tract (Niessen et al. 2005). The two smooth muscle layers of the intestine are enlarged, being approximately four times as thick as in wild-type mice. However, the maximal contractile force, even after correction for muscle area, is only about $20 \%$ of wild-type mice. This results in decreased peristalsis and subsequently starvation and death. A similar decrease in contractility has been observed in the vasculature of these mice and in mice only deficient in smoothelin-B (Niessen et al. 2004b). Therefore, we can generalize that lack of smoothelin leads to a decreased contractile potential of SMCs. In case of a peristaltic contraction pattern, as in the intestine, this completely blocks functional contraction. In case of tonic contraction, as in blood vessels, the effect is less deleterious because neural or hormonal compensation may neutralize the decreased contractile potential. The data obtained from the knockout mice, so far, confirm smoothelin as a structural component of the contractile apparatus.

\section{- Conclusion}

Although smoothelin has become one of the preferred markers to characterize the contractile phenotype of SMCs, knowledge about its function is limited. The available data suggest that smoothelin is part of, or associated with, the contractile apparatus of SMCs. There is no evidence that smoothelin actively affects phenotypic modulation. Its function may be similar to that of caldesmon, which increases the contractile potential of SMCs and contributes to the maintenance of the contractile phenotype. Absence of smoothelin, and the consequent substantial reduction in contractile force, eventually leads to disruption of phasic contractions but affects tonic contractions to a lesser degree. Identification of other molecules of the SMC contractile apparatus that interact with smoothelins will be necessary to elucidate its function and mode of action.
Bar H, Wende P, Watson L, et al.: 2002. Smoothelin is an indicator of reversible phenotype modulation of smooth muscle cells in balloon-injured rat carotid arteries. Basic Res Cardiol 97:9-16.

Chamley-Campbell J, Campbell GR, Ross R: 1979. The smooth muscle cell in culture. Physiol Rev 59:1-61.

Christen T, Bochaton-Piallat ML, Neuville P, et al.: 1999. Cultured porcine coronary artery smooth muscle cells. A new model with advanced differentiation. Circ Res 85: 99-107.

Christen T, Verin V, Bochaton-Piallat ML, et al.: 2001. Mechanisms of neointima formation and remodeling in the porcine coronary artery. Circulation 103:882-888.

De Ruiter MC, Rensen SS, Coolen GP, et al.: 2001. Smoothelin expression during chicken embryogenesis: detection of an embryonic isoform. Dev Dyn 221:460-463.

Gimona M, Djinovic-Carugo K, Kranewitter WJ, Winder SJ: 2002. Functional plasticity of CH domains. FEBS Lett 513:98-106.

Guo H, Wang CL: 2005. Specific disruption of smooth muscle caldesmon expression in mice. Biochem Biophys Res Commun 330: $1132-1137$.

Hai CM, Gu Z: 2006. Caldesmon phosphorylation in actin cytoskeletal remodeling. Eur J Cell Biol 85:305-309.

Hao H, Ropraz P, Verin V, et al.: 2002. Heterogeneity of smooth muscle cell populations cultured from pig coronary artery. Arterioscler Thromb Vasc Biol 22:1093-1099.

Hao H, Gabbiani G, Camenzind E, et al.: 2006. Phenotypic modulation of intima and media smooth muscle cells in fatal cases of coronary artery lesion. Arterioscler Thromb Vasc Biol 26:326-332.

Johansson B, Eriksson A, Ramaekers F, Thornell L: 1999. Smoothelin in adult and developing human arteries and myocardium. Histochem Cell Biol 112: 291-299.

Johnson JL, van Eys GJ, Angelini GD, George SJ: 2001. Injury induces dedifferentiation of smooth muscle cells and increased matrix-degrading metalloproteinase activity in human saphenous vein. Arterioscler Thromb Vasc Biol 21:1146-1151.

Korenbaum E, Rivero F: 2002. Calponin homology domains at a glance. J Cell Sci 115:3543-3545.

Maeng M, Mertz H, Nielsen S, et al.: 2003. Adventitial myofibroblasts play no major role in neointima formation after angioplasty. Scand Cardiovasc J 37:34-42.

Miano J: 2003. Serum response factor: toggling between disparate programs of gene expression. J Mol Cell Cardiol 35:577-593.

Morrow D, Scheller A, Birney YA, et al.: 2005. Notch-mediated CBF-1/RBP-J\{kappa dependent regulation of human vascular smooth muscle cell phenotype in vitro. Am J Physiol Cell Physiol 289:C1188-C1196. 
Niessen P, Clement S, Fontao L, et al.: 2004a. Biochemical evidence for interaction between smoothelin and filamentous actin. Exp Cell Res 292:170-178.

Niessen P, Rensen S, Gijbels M, et al.: 2004b. Impaired smooth muscle contractility in smoothelin deficient mice results in lethality. Cardiovasc Pathol 13:38.

Niessen P, Rensen S, Van Deursen J, et al.: 2005. Smoothelin-a is essential for functional intestinal smooth muscle contractility in mice. Gastroenterology 129: $1592-1601$.

Niu Y, Xu Y, Zhang J, et al.: 2001. Proliferation and differentiation of prostatic stromal cells. BJU Int 87:386-393.

Owens GK: 1995. Regulation of differentiation of vascular smooth muscle cells. Physiol Rev 75:487-517.

Owens GK, Kumar MS, Wamhoff BR: 2004. Molecular regulation of vascular smooth muscle cell differentiation in development and disease. Physiol Rev 84:767-801.

Quensel C, Kramer J, Cardoso MC, Leonhardt H: 2002. Smoothelin contains a novel actin cytoskeleton localization sequence with similarity to troponin T. J Cell Biochem 85:403-409.

Rensen S, Thijssen V, De Vries C, et al.: 2002. Expression of the smoothelin gene is mediated by alternative promoters. Cardiovasc Res 55:850-863.

Rensen SS, Niessen PM, Long X, et al.: 2006. Contribution of serum response factor and myocardin to transcriptional regulation of smoothelins. Cardiovasc Res 70:136-145.

Rodriguez LV, Alfonso Z, Zhang R, et al.: 2006. Clonogenic multipotent stem cells in human adipose tissue differentiate into functional smooth muscle cells. Proc Natl Acad Sci U S A 103:12167-12172.

Seow CY: 2005. Myosin filament assembly in an ever-changing myofilament lattice of smooth muscle. Am J Physiol Cell Physiol 289:C1363-C1368.

Tharp DL, Wamhoff BR, Turk JR, Bowles DK: 2006. Upregulation of intermediate-conductance $\mathrm{Ca} 2+$-activated $\mathrm{K}+$ channel (IKCa1) mediates phenotypic modulation of coronary smooth muscle. Am J Physiol Heart Circ Physiol.

van der Heijden OW, Essers YP, Simkens LH, et al.: 2004. Aging blunts remodeling of the uterine artery during murine pregnancy. J Soc Gynecol Investig 11:304-310.

van der Loop FT, Schaart G, Timmer ED: 1996. Smoothelin, a novel cytoskeletal protein specific for smooth muscle cells. J Cell Biol 134:401-411.

van der Loop FT, Gabbiani G, Kohnen G, et al.: 1997. Differentiation of smooth muscle cells in human blood vessels as defined by smoothelin, a novel marker for the contractile phenotype. Arterioscler Thromb Vasc Biol 17:665-671.

van der Veer E, Nong Z, O'Neil C, et al.: 2005. Pre-B-cell colony-enhancing factor regulates NAD+-dependent protein deacetylase activity and promotes vascular smooth muscle cell maturation. Circ Res 97:25-34.

Verhamme P, Quarck R, Hao H, et al.: 2002. Dietary cholesterol withdrawal reduces vascular inflammation and induces coronary plaque stabilization in miniature pigs. Cardiovasc Res 56:135-144.
Yoshida T, Kawai-Kowase K, Owens GK: 2004. Forced expression of myocardin is not sufficient for induction of smooth muscle differentiation in multipotential embryonic cells. Arterioscler Thromb Vasc Biol 24:1596-1601.

\title{
AT 1 Receptors and Control of Blood Pressure: The Kidney and More...
}

\author{
Steven D. Crowley, Susan B. Gurley, and Thomas M. Coffman*
}

The renin-angiotensin system (RAS) is a critical regulator of blood pressure and fluid homeostasis. The components of the RAS including renin, angiotensin-converting enzyme, and angiotensin receptors are expressed throughout the body in tissues that may impact blood pressure control. Blocking actions of individual components of the RAS including renin, angiotensin-converting enzyme, or the type $1\left(A T_{1}\right)$ receptor lowers blood pressure. Although it has been suggested that control of sodium excretion by the kidney is the dominant mechanism for blood pressure regulation by the RAS, pharmacologic antagonists or conventional gene-targeting experiments globally interrupt the RAS and cannot discriminate its actions in the kidney from other tissue compartments. Recent experiments with the use of kidney cross-transplantation and genetically engineered mice suggest independent and equivalent effects of angiotensin II acting via $A T_{1}$ receptors in the kidney and in extrarenal tissues to maintain the normal level of blood pressure. However, the nature and relative contributions of these actions may differ in hypertension. (Trends Cardiovasc Med 2007;17:30-34) (C) 2007, Elsevier Inc.

\section{- The Renin-Angiotensin System Regulates Blood Pressure}

The renin-angiotensin system (RAS) is a master regulator of blood pressure and

Steven D. Crowley, Susan B. Gurley, and Thomas M. Coffman are at the Division of Nephrology, Department of Medicine, Duke University and Durham VA Medical Centers, Durham, NC, 27710 USA.

* Address correspondence to: Thomas M. Coffman, Building 6/Nephrology (111I), VA Medical Center, 508 Fulton Street, Durham, NC 27705, USA. Tel.: (+1) 919-286-6947; fax: (+1) 919-286-6879; e-mail: tcoffman@acpub.duke.edu.

(C) 2007, Elsevier Inc. All rights reserved. 1050-1738/07/\$-see front matter fluid homeostasis (Husain and Graham 2000). Accordingly, specific inhibitors of renin, angiotensin-converting enzyme, or $\mathrm{AT}_{1}$ angiotensin receptors dramatically lower blood pressure in patients with hypertension and may slow the progression of renal and cardiovascular disease (1987, Husain and Graham 2000, Brenner et al. 2001, Cohn and Tognoni 2001). Similarly, mice homozygous for null mutations in the genes encoding angiotensinogen, renin, angiotensin-converting enzyme, or $\mathrm{AT}_{1 \mathrm{~A}}$ receptor, the closest murine homologue to the single human $\mathrm{AT}_{1}$ receptor gene, have marked and equivalent reductions in blood pressure, indicating that these genes constitute a pathway mediating the major 